\title{
THE INFLUENCE OF FOREIGN DIRECT INVESTMENT AND PUBLIC INCENTIVES ON THE SOCIO-ECONOMIC DEVELOPMENT OF REGIONS: AN EMPIRICAL STUDY FROM THE CZECH REPUBLIC
}

\section{Petr Hlaváček, Julius Janáček}

\section{Introduction}

In the transitional economies of Central and Eastern Europe after the completion of the privatization process, there was increased pressure to win foreign investment to support the ongoing economic transformation. Countries systematically dealt with the problem of a lack of foreign investments (Švejnar, 2002; Hardy et al., 2011). For this reason, in the Czech Republic and in other post-communist countries an incentive system was created for foreign investors (Ginevičius \& Šimelytè, 2011). The aim was to increase the attractiveness of the economy for foreign investors in competition with other countries, which also created their own incentive systems. In the Czech legislation, a foreign investor is defined as a company that establishes or expands its representation as a foreign investor in the host economy, which includes acquiring at least $10 \%$ of the share of the assets and/or voting rights in a company.

The development of localization of foreign direct investment in the Czech Republic and in the other countries of Central Europe has been the subject of numerous studies (Kornecki \& Raghavan, 2011; Gauselmann, Knell, \& Stephan, 2011; Domanski \& Guzik, 2009). If we interpret their results, it is apparent that the flows of foreign direct investment were affected by regionally specific localization conditions, which created a differentiated economic and social environment, with varying attractiveness for foreign direct investment (Santos-Paulino, Squicciarini, \& Fan, 2014).

The concentration of foreign direct investment has an impact on the economic environment of the region in a number of areas (Gersbach \& Schmutzler, 2011; Alazzawi, 2012).
The effect on the inflow of foreign direct investment on economic growth in mediumdeveloped countries is not always clear. Alvarado, Iñiguez and Ponce (2017) did not confirm a statistically significant dependence in Latin America but in the case of Central European countries, a positive correlation was found (Fidrmuc \& Martin, 2011; Tuan, Ng, \& Bo, 2009). This can be explained by other initial economic conditions and the necessity of a complex economic transformation (Hlaváček \& Bal-Domańska, 2016). In general, investment in GDP growth contributes to the regional economy (Bajo-Rubio et al., 2007), while enterprises in the region are more integrated into global production chains in subcontracting (Wei et al., 2012; Pelinescu \& Radulescu, 2009). According to Mukherjee and Sinha (2016), growth in competition has a positive effect on the decline in producer prices for consumers. The number of jobs, labor productivity and reskilling are expected to grow as well (Javorcik, 2012). Very often, a positive impact on the growth of research and development (R\&D) activities is also mentioned (Santos-Paulino et al., 2014; Chen \& Yang, 2013; Blomström \& Sjöholm, 1999). New knowledge, know-how and spillover effects are flowing into the region with the inflow of foreign direct investment, according to the intensity of interconnection of local companies with foreign companies. Todo and Miyamoto (2006) point to this effect with examples coming from Japanese companies. Gersbach and Schmutzler (2011), Chen and Yang (2013) are also expected to influence the development of Science and Research expenditures (in this article, science and research expenditures refer to the same aspect as R\&D expenditures). 
In the list of negatives, the most important risk is the instability of localization - the investors may move production to other countries following the expiry of contractual arrangements. Another risk for the region is the crowding-out of domestic firms, which, according to Srholec (2004), are not sufficiently competitive because of the incentive system for foreign companies. Alazzawi (2012) confirms this by showing that the inflow of foreign direct investment increases competitive pressure on domestic firms. On the other hand, an analysis of companies in Spain shows that the inflow of foreign investors has led to growth in competitiveness and production efficiency in local firms (García et al., 2013). Within the overall context there are more positive effects which are reinforced by the need for the transformation of economic structures in transitional economies (Tvrdoň \& Skokan, 2012). Each type of region has individual localization prerequisites for the inflow of new investments, due to the fact that regions have varying attractiveness and diversified economic growth. Therefore, an incentive system has been created for investors that motivates more investors to locate branches in problematic regions (Šimelytè \& Liučvaitienè, 2012; Meriküll et al., 2013). The investment incentives have gradually become a regular socio-political tool in developed and developing countries. An investment incentive is generally defined as an advantage and motivational tool, through which the government wants to influence the companies' decision to localize investments, particularly in less developed regions. The reason for providing such incentives is to attract new investment or maintain existing businesses as measures against economic stagnation and decline of a region. Providing investment incentives has several advantages and disadvantages. The national and local governments can use an investment system relatively effectively for the transformation and modernization of the sectoral or spatial structure of the economy. Another advantage is the transfer of modern technologies to the region or the creation of new jobs. However, the effect of reducing the level of unemployment is only partial because workers are often taken from another companies and pressure may be imposed on local businesses. On the other hand, the creation of new jobs and subcontracting links for local businesses can be initiated.
Investors have the opportunity in the Czech Republic to use various types of investment incentives: exemption from property tax, aid for the creation of new jobs and retraining or the training of new employees, corporate tax relief and contributions for the acquisition of property. If expansion or the implementation of a new production occurs, both in the processing industry as well as in the technological centre, material support may reach as much as $12.5 \%$ of eligible costs. In the case of strategic investment in production, this support may reach a maximum of 1.5 bil. CZK. For a technology centre, the maximum is 500 mil. CZK. The last usable form of support is the transfer of land, including infrastructure, for a discounted price.

The system for granting selective incentives carries the risk of excessive subsidy, which may be caused by great competition among governments in Central Europe. Any positive effects for the economy as a whole therefore can be easily turned into higher profits for the investor, who after several years may sell the branch and realize investments in another country, again with public support. It is also the case that some investment incentives can be gained by investors who would realize a particular investment even without the provided investment incentives. The effects of a localization decision are very extensive. According to a study from Deloitte (2010), with the support of investment incentives many new jobs have been created, of which a quarter were created directly in supported companies and three quarters in subcontracting networks. A localized branch in the region in the form of domestic or foreign investments may cause some positive multiplication effect, manifested in other indicators and in the comprehensive development of the region. An example may be the localization of new production, improving relationships with regional supplier companies, which also increases their innovative capacity (Bučar et al., 2009).

With inflows of foreign direct investment and investment incentives, such cash flow can also be expected to lead to the development of companies in the region and to increase their innovation potential. This should also increase growth and expenditures for science and research due to spillover effects between R\&D and companies (Autant-Bernard \& LeSage, 2011). The problem of regions with a lower potential of economic growth and lower 
competitiveness lies in the lower level of activity of the businesses in the areas of research, development and innovation. In the less successful regions, it is therefore necessary to have a higher level of public support for the development of R\&D, since according to Kroll et al. (2009) the scope of the R\&D activities also affects the quality of the regional environment.

The aim of this article is to identify how the different financial flows are reflected in the development of the regions, through the analysis of selected social and economic indicators. In this case, examination will be carried out of foreign direct investment (FDI), government investment incentives (GII) as well as science and research expenditures (SaRE). So far, no study has been conducted in the area of FDI, GII and SaRE, that would encompass analysis and connections with as many indicators as our study. This complex approach offers new possibilities of research. Studying the effect of FDI, GII and SaRE on characteristics of regions connected with the labor market, population growth and migration as well as construction activity can yield new insight as well as unique results, which can contribute to the research in this field in original way. Although our approach is relatively complex, we must note that many important indicators as well as independent variables were not included into our study while we recommend that this be done in future research.

\section{Methodology and Data}

In the interest of gaining more detailed information about spatial differences and conditions for development processes, in terms of the hierarchy of territorial units, the level of districts was used (NUTS III). By doing this, there was a more extensive sampling and the identification of spatial specifics could be conducted compared to using the level of regions (NUTS II). Our dataset is cross-sectional based on these regions without Prague. The reason why we excluded Prague from our dataset is that it is a completely different environment with different structures. The predictors of regional development indicators are presented in Tab. 1.

The source of data on inflows of foreign direct investment in the districts is the Czech National Bank, which keeps track of the flows of foreign investment. The data for provided investment incentives for individual investors, which may be either of foreign or domestic origin, originate from sources of the government agency for support of investments (Czechlnvest, 2017), which has been aggregated for individual incentives at the level of districts (Tab. 1).

Firstly, we analyzed data for foreign direct investment between the years 2000-2015. The average FDI over all regions over the time period between 2000 and 2015 is 657.6 million CZK per year. There is a sharp increase in 2007 and a decline during 2013-2015. During 2013 and 2015, the averages over all Czech regions were even negative. This means that during these years, investment money was flowing out of the country at a higher level than foreign direct investment was flowing into the Czech regions.

Foreign direct investment inflows have usually acquired positive values, but they can

\section{Tab. 1: Investigated independent variables}

\begin{tabular}{l|l|c|l}
\multicolumn{1}{c|}{ Variable } & \multicolumn{1}{c|}{ Code } & $\begin{array}{c}\text { Number } \\
\text { of variables } \\
\text { (years) }\end{array}$ & \multicolumn{1}{c}{ Source } \\
\hline $\begin{array}{l}\text { Government investment } \\
\text { incentives for firms between } \\
\text { the years 2000-2016 (district } \\
\text { level, mil. CZK) }\end{array}$ & Incentive_2000-2016 & 17 & $\begin{array}{l}\text { Czechlnvest } \\
\text { database (2017) }\end{array}$ \\
\hline $\begin{array}{l}\text { Foreign direct investments total } \\
\text { between the years 2000-2015 } \\
\text { (district level, thous. CZK) }\end{array}$ & FDI_2000-2015 & 16 & $\begin{array}{l}\text { Czech National } \\
\text { Bank (2017) }\end{array}$ \\
\hline $\begin{array}{l}\text { SaRE Expenditure between } \\
\text { the years 2009-2015 (district } \\
\text { level; mil. CZK) }\end{array}$ & Research_2009-2015 & 7 & $\begin{array}{l}\text { Czech Statistical } \\
\text { Office (2017) }\end{array}$ \\
\hline
\end{tabular}

Source: own based on CzechInvest, Czech National Bank, Czech Statistical Office 
also report negative values. In this case, there is a situation when the inflow of FDI is lower than the outflow of FDI. This can be the result of an economic recession or the saturation of the Czech economy. This situation in the Czech Republic has been linked to the onset of the economic crisis in 2008 when companies significantly reduced their investments, as described by (Novák \& Drdová, 2018). Another explanation is given by (Dunning, 2018) who says that in a certain phase, saturation of the local environment with direct foreign investments occurs and the host economy is already so developed that companies are able to a greater extent to invest abroad, while the result of that could also be a negative difference between the inflow and outflow of investments.

However, from a geographical point of view, in the placement and flows of FDI, there is spatial differentiation in regionally specific types of territories. Examples of this are urban versus rural regions, metropolitan versus nonmetropolitan areas.

Secondly, we have a series of data for government financial incentives of the Czech Republic. This series goes from 1998 to 2017. Out of 1,520 ( 76 regions $\times 20$ years) cell values, 1,019 were equal to 0 , which means that there were no government incentives in the given region in the given year.

The government's approach to investment incentives in the past 18 years has changed several times. At present, under Act No. 84/2015 Coll., three areas of foreign investment are supported - the introduction or the expansion of production in the processing industry, construction or expansion of a technological centre as well as the development of strategic centers specialized in software development and high-tech service centers.

According to Czech Statistical Office (2019), expenditure on research and development is normal cost incurred within an institution or organization for research and development regardless of the source of their funding. The amount of expenditure on science and research varies among regions in the long run. Differentiation points to the absorption capacity and the research potential of the region and the financing of SaRE depends on these characteristics. We can build on the theory of regional innovation systems (Cooke, 2001; Asheim \& Coenen, 2005), where the location of the research and development institutions or activities reinforces the innovative potential of the region.

The average value of SaRE for all regions over the time period between 2009 and 2015 is 367 million CZK per year. If we take into account only non-zero cells, we come up with an average of 415 million CZK per year.

A sharp difference is apparent: while FDI are sharply decreasing between the years 2012-2015, science and research expenditures are rising. Whether this has some consequence for the development of regions in this time, we will see in model.

There are another 13 variables that we work with in addition to those presented in Tab. 1. Our analysis is based on regression models. Firstly, we use these 13 characteristics as dependent variables. Also, in the models we use them as independent variables in order to control for their effects. This data originates from the database of the Czech Statistical Office. An overview of used data, including the summary of statistics, can be found in Tab. 2 .

During the selection of data, the aim was to maintain a complex approach in mapping social and economic changes. Therefore, such indicators were selected in relation to which it is possible to expect a certain reaction to the inflow of finances into the territory. The social area is represented by indicators such as the number of inhabitants, the numbers of foreigners and the urbanization rate. The labor market is represented by data about the number of unemployed people and the numbers of available jobs. This is due to the fact that some authors (Driffield \& Taylor, 2000; Bandelj, 2002) argue that the inflow of FDI stimulates employment growth. The growth of the population can also be expected as a result of FDI inflow.

According to Ascani and lammarino (2018) FDI inflow will also be reflected in the migration of citizens and the change of cultural relations between investors and the local environment. Thus, data concerning immigration and the number of foreign workers will also be included in the model. The insertion of the last indicator is also based on current experience; many industrial companies employ more foreign workers due to the lack of a domestic labor force.

In the economic area, numbers of companies are monitored in the categories of small, medium-sized and large businesses and 


\section{Economics}

\section{Tab. 2: Dependent variables and control variables}

\begin{tabular}{|c|c|c|c|c|c|c|c|}
\hline Variable name & Variable description & Code & Mean & Median & Min & $\operatorname{Max}$ & Std. Dev. \\
\hline Population_2015 & Population (2015) & Po15 & 122,189 & 111,371 & 39,261 & 37,7028 & 58,183 \\
\hline dPopulation_2015 & $\begin{array}{l}\text { Population } \\
(2015-2014)\end{array}$ & $\mathrm{dPo} 15$ & 94.7105 & -15.5 & $-2,427$ & 3,849 & 800.4 \\
\hline Unemploy_2015 & $\begin{array}{l}\text { Number of unemployed } \\
(2015)\end{array}$ & Un15 & $5,472.4$ & 4,790 & 1,292 & 2,2754 & $3,786.3$ \\
\hline dUnemployed_2015 & $\begin{array}{l}\text { Number of unemployed } \\
(2015-2014)\end{array}$ & dUn15 & $-1,085.7$ & $-1,009$ & $-2,975$ & -139 & 561.9 \\
\hline JobsFree_2015 & Jobs free (2015) & JF15 & $1,155.3$ & 985.5 & 224 & 3,939 & 671.7 \\
\hline dJobsFre_2015 & Jobs free (2015 - 2014) & dJF15 & 506.39 & 413 & 3 & 1,784 & 374.2 \\
\hline Active_2015 & $\begin{array}{l}\text { Economically active } \\
\text { people (2015) }\end{array}$ & A15 & 80,957 & 73,194 & 26,334 & 24,6583 & 38,501 \\
\hline dActive_2015 & $\begin{array}{l}\text { Economically active } \\
\text { people }(2015 \text { - 2014) }\end{array}$ & $\mathrm{dA15}$ & -751.0 & -710.5 & $-3,160$ & 1,539 & 629.4 \\
\hline Urban_2014 & Urbanization 2014 & Ur15 & 62.482 & 60.35 & 34.75 & 100 & 14.8 \\
\hline FirmsSma_2015 & $\begin{array}{l}\text { Number of small firms } \\
(2015)\end{array}$ & FS15 & $2,607.8$ & 2,189 & 753 & 15,628 & $2,020.1$ \\
\hline dFirmsSma_2015 & $\begin{array}{l}\text { Small firms } \\
(2015-2014)\end{array}$ & $\mathrm{dFS} 15$ & -8.3684 & -10 & -69 & 121 & 31.5 \\
\hline FirmsMed_2015 & $\begin{array}{l}\text { Number of medium firms } \\
(2015)\end{array}$ & FM15 & 110.67 & 96 & 26 & 566 & 74.9 \\
\hline dFirmsMed_2015 & $\begin{array}{l}\text { Number of med. firms } \\
(2015-2014)\end{array}$ & dFM15 & 0.447 & 0 & -12 & 15 & 4.5 \\
\hline FirmsLarg_2015 & $\begin{array}{l}\text { Number of large firms } \\
(2015)\end{array}$ & FL15 & 21.026 & 15 & 4 & 123 & 18.7 \\
\hline dFirmsLarg_2015 & $\begin{array}{l}\text { Number of large firms } \\
(2015-2014)\end{array}$ & dFL15 & 0.6579 & 1 & -6 & 5 & 1.8 \\
\hline Foreigners_2015 & $\begin{array}{l}\text { Number of foreigners } \\
(2015)\end{array}$ & F15 & $3,848.8$ & 2,533 & 811 & 24,850 & $3,654.4$ \\
\hline dForeigners_2015 & $\begin{array}{l}\text { Number of foreigners } \\
(2015 \text { - 2014) }\end{array}$ & $\mathrm{dF} 15$ & 133.78 & 83.5 & -181 & 1,169 & 194.9 \\
\hline Immigrants_2015 & $\begin{array}{l}\text { Number of immigrants } \\
\text { (from other dist.) } 2015\end{array}$ & $\operatorname{Im} 15$ & $1,819.9$ & 1,353 & 375 & 8,934 & $1,424.1$ \\
\hline $\begin{array}{l}\text { BuildPermits } \\
\text { 2015 }\end{array}$ & $\begin{array}{l}\text { Number of building } \\
\text { permits (2015) }\end{array}$ & BP15 & 977.61 & 844.5 & 252 & 2,822 & 493.5 \\
\hline $\begin{array}{l}\text { Building Total } \\
\text { _2015 }\end{array}$ & $\begin{array}{l}\text { Approximate value of } \\
\text { constructions (mil. CZK) }\end{array}$ & BT15 & $2,367.5$ & 2,047 & 543 & 9,343 & $1,479.9$ \\
\hline $\begin{array}{l}\text { BuildPermitsResid } \\
2015\end{array}$ & $\begin{array}{l}\text { Number of residual } \\
\text { build. perm. gr. (2015) }\end{array}$ & BPR15 & 341.79 & 298.5 & 68 & 1,127 & 203.8 \\
\hline $\begin{array}{l}\text { ValueResident } \\
2015\end{array}$ & $\begin{array}{l}\text { Approx. value of resid. } \\
\text { building } 2015 \text { (mil. CZK) }\end{array}$ & VR15 & 850.08 & 658.5 & 133 & 4,117 & 677.2 \\
\hline
\end{tabular}

Source: own based on CzechInvest, Czech National Bank, Czech Statistical Office 
construction activity, including the average cost of construction. According to Munemo (2017) the influx of FDI stimulates the emergence of new start-ups and the creation of new businesses. Sajid and Sizhong (2016) also pointed out that the export potential of local businesses is increasing as well. According to Albulescu and Tamasila (2014), FDI inwards also positively influenced the opportunity-driven entrepreneurs. The impact on local businesses is also described by Javorcik (2012), who points to positive productivity spillovers from FDI to local suppliers.

Indicators concerning construction activity generally indicate the growth potential of a territory. The positive influence of foreign investment on the building development of a region is evidenced by Chen, Melachroinos and Chang (2010). For this reason, the model also includes data from the construction and real estate markets, specifically data for the average value of buildings and the number of building permits. The insertion of this data is also based on the fact that the intensity of construction activity is an indicator of the development dynamics of the territory.

For the variable Urbanization, we only have data for the year 2014. However, since the Urbanization rate is a relatively stable value, we can assume that in the year 2015 the values for all regions will be very similar that of 2014 . For the other 12 variables, we have values for 2014 and 2015. Sometimes, we only need values for the year 2015. Since we investigate what effect FDI, SaRE and GII have on the region, it is sometimes necessary to work with the differential value during the years 2014 and 2015. To calculate this, we also need the value for the year 2014.

We named differential variables "d..._2015". For example, "dPopulation_2015" stands for the difference of population for the given region during the years 2014 and 2015 (Tab. 3). We could try transforming our data (for example logarithmically). However, for the sake of mathematical clarity, we stick to initial models with no transformations.

\section{Results and Discussion}

Our goal is to determine the influence of FDI, SaRE and GII on various characteristics of the regions presented in Tab. 2. Technically, it would be optimal to use panel regression with a long enough data series. This model would yield more precise results. Although our dataset is quite large, this is not enough to perform panel regression (especially in the case of dependent variables). For this reason, we used a different technique. We created a linear OLS regression model for each characteristic of a region that we wanted to study. The mathematical model is introduced in the following formula.

$$
\begin{aligned}
& y_{i}=\beta_{0}+\beta_{1} x_{i 1}+\cdots+\beta_{p} x_{i p}+ \\
& +\varepsilon_{i}=x_{i}^{T} \beta+\varepsilon_{i}, i=1, \ldots, n \\
& \left\{y_{i}, x_{i 1}, \ldots, x_{i p}\right\}_{i=1}^{n}
\end{aligned}
$$

Letter $y$ stands for the dependent variable. Names of dependent variables used in our models are in the first row of Tab. 3. Letter $x$ stands for independent variables $\left(x_{i l}, \ldots, x_{i p}\right)$. In our case, the names of these are presented in the first column of Tab. 3. Letter $n$ is the number of regions we use for our models. $\beta_{0, \ldots,} \beta_{p}$ are the coefficients that we estimate in each of the regression equations. These numbers are the outcome of regression models that we used. Again, we can find them in Tab. 3 - all the numbers with the exception of those in the last row.

In these models the dependent variable is either the value for the year 2015 or value for the difference between the values in 2014 and 2015. For example, we studied the effect of FDI and other independent variables on the difference in small firms during the years 2014 and 2015.

We are aware of the fact that in this way we only use the information of dependent variables for the years 2014 and 2015, whereas panel regression would use data for a long time series but as explained before, for this technique sufficient data is not available. With the data that we have, our model is the most precise technique that can be applied.

In each of our models the independent variables are the FDI for the years between 2000-2015, science and research expenditures for the years between 2009-2015, government financial incentives for the years between 1998-2016 and control variables that can also influence the dependent variables. The results are presented in Tab. 3. This table shows the estimated coefficients of the independent variables. Each column stands for one linear regression model whose dependent variable is in the top cell of the column. Each row stands for one independent variable. In the last row of the table, we present the R-squared coefficients. 


\section{Tab. 3: Results of OLS regression models (Part 1)}

\begin{tabular}{|c|c|c|c|c|c|c|c|c|c|}
\hline Regressor & dPo15 & dA15 & dFS15 & dFM15 & dF15 & $\operatorname{Im} 15$ & dBP15 & BPR15 & VR15 \\
\hline const & 155.59 & 407.35 & -9.924 & 0.190 & -129.3 & 243.11 & -103.4 & -5.969 & 154.043 \\
\hline FDI_00 & 2.4E-05 & $-3.2 \mathrm{E}-06$ & $-3.2 \mathrm{E}-07$ & $3.6 \mathrm{E}-07$ & $-2.0 \mathrm{E}-05$ & $-5.9 \mathrm{E}-05$ & $1.9 \mathrm{E}-05$ & $6.1 \mathrm{E}-06$ & $-2.1 \mathrm{E}-06$ \\
\hline FDI_01 & $-4.7 \mathrm{E}-06$ & $2.6 \mathrm{E}-05$ & $6.5 \mathrm{E}-06^{*}$ & $-8.4 \mathrm{E} 07^{*}$ & $-1.6 \mathrm{E}-05$ & $-5.6 \mathrm{E}-05$ & $1.6 \mathrm{E}-05$ & $1.1 \mathrm{E}-05$ & $3.2 \mathrm{E}-06$ \\
\hline FDI_02 & $-2.8 \mathrm{E}-05$ & $-1.2 \mathrm{E}-05$ & $1.0 \mathrm{E}-05^{* * *}$ & $-1.3 \mathrm{E}-07$ & $5.1 \mathrm{E}-06$ & $7.3 \mathrm{E}-05^{*}$ & $4.2 \mathrm{E}-05^{*}$ & $-1.5 \mathrm{E}-06$ & $-1.7 \mathrm{E}-05$ \\
\hline FDI_03 & $9.1 \mathrm{E}-06$ & $-1.5 \mathrm{E}-05$ & $1.6 \mathrm{E}-06$ & $-3.8 \mathrm{E}-07$ & $1.6 \mathrm{E}-05$ & $6.5 \mathrm{E}-05$ & $-5 . E-05^{* *}$ & $-8.3 \mathrm{E}-06$ & $1.9 \mathrm{E}-05$ \\
\hline FDI_04 & 1.7E-05 & $2.1 \mathrm{E}-05$ & $3.8 \mathrm{E}-06^{*}$ & $2.9 \mathrm{E}-07$ & $6.1 \mathrm{E}-06$ & $5.0 \mathrm{E}-06$ & $1.2 \mathrm{E}-05$ & $3.1 \mathrm{E}-06$ & $2.2 \mathrm{E}-07$ \\
\hline FDI_05 & $1.1 \mathrm{E}-05$ & $2.5 \mathrm{E}-06$ & $5.6 \mathrm{E}-06^{* \star *}$ & $-3.7 \mathrm{E}-07$ & $-1.5 \mathrm{E} 05^{*}$ & $8.6 \mathrm{E}-06$ & 4.E- $05^{\star \star *}$ & $2.2 \mathrm{E}-06$ & $-1.9 \mathrm{E}-05^{\star *}$ \\
\hline FDI_06 & $3.3 \mathrm{E}-05$ & $7.4 \mathrm{E}-06$ & $8.0 \mathrm{E}-06^{* *}$ & $1.1 \mathrm{E} 06^{* *}$ & $-1.5 \mathrm{E}-05$ & $-2.2 \mathrm{E}-05$ & 4.7E-06 & $-7.7 \mathrm{E}-07$ & $1.2 \mathrm{E}-05$ \\
\hline FDI_07 & $1.1 \mathrm{E}-05$ & $-1.6 \mathrm{E}-06$ & $1.1 \mathrm{E}-06$ & $-2.7 \mathrm{E}-07$ & $-5.3 \mathrm{E}-06$ & $-1.4 \mathrm{E}-05$ & $-4 . E-05^{* * *}$ & $-4.4 \mathrm{E}-06$ & $1.9 \mathrm{E}-05^{* *}$ \\
\hline FDI_08 & $-8.2 \mathrm{E}-06$ & $-1.1 \mathrm{E}-05$ & $-1.9 \mathrm{E}-06$ & $-5.6 \mathrm{E}-07$ & $-1.7 \mathrm{E}-05$ & $-2.2 \mathrm{E}-05$ & $-5 . E-05^{* * *}$ & $5.0 \mathrm{E}-06$ & $2.3 \mathrm{E}-05$ \\
\hline FDI_09 & $4.1 \mathrm{E}-05$ & 2.4E-05 & $-3.1 \mathrm{E}-06$ & $1.4 \mathrm{E}-07$ & $8.9 \mathrm{E}-06$ & $-6.8 \mathrm{E} 05^{*}$ & $1.3 \mathrm{E}-05$ & $1.1 \mathrm{E}-05$ & $-3.2 \mathrm{E}-07$ \\
\hline FDI_10 & $2.9 \mathrm{E}-05$ & $5.2 \mathrm{E}-06$ & $7.4 \mathrm{E}-08$ & $1.2 \mathrm{E}-07$ & $-2.3 \mathrm{E}-06$ & $-1.7 \mathrm{E}-06$ & $-3 . E-05^{* *}$ & $-4.9 \mathrm{E}-06$ & $1.7 \mathrm{E}-05^{* *}$ \\
\hline FDI_11 & $-1.0 \mathrm{E}-05$ & $6.9 \mathrm{E}-06$ & $-4.8 \mathrm{E}-06$ & $3.3 \mathrm{E}-07$ & $2.9 \mathrm{E}-05$ & $5.0 \mathrm{E}-05$ & $-1.5 \mathrm{E}-05$ & $1.1 \mathrm{E}-05$ & $3.3 \mathrm{E}-06$ \\
\hline FDI_12 & $-1.2 \mathrm{E}-05$ & $-2.3 \mathrm{E}-05$ & $-6.6 \mathrm{E}-06^{*}$ & $-6.5 \mathrm{E}-07$ & $-3.6 \mathrm{E}-06$ & $4.5 \mathrm{E}-06$ & $-8.9 \mathrm{E}-06$ & $-6.0 \mathrm{E}-06$ & $9.3 \mathrm{E}-07$ \\
\hline FDI_13 & 7.7E-05 & $-1.6 \mathrm{E}-06$ & $3.0 \mathrm{E}-06$ & $5.6 \mathrm{E}-07$ & $-1.7 \mathrm{E}-06$ & $-2.0 \mathrm{E}-05$ & $-1.3 \mathrm{E} 04^{* * *}$ & $-2 . E 05^{* *}$ & $5 . E-05^{* * *}$ \\
\hline FDI_14 & $1.8 \mathrm{E}-05$ & 7.2E-06 & 3.7E- $06^{*}$ & $1.2 \mathrm{E}-07$ & $9.1 \mathrm{E}-06$ & $-6.4 \mathrm{E}-06$ & $-6.5 \mathrm{E}-06$ & $-2.8 \mathrm{E}-06$ & $1.3 \mathrm{E}-05$ \\
\hline FDI_15 & $2.5 \mathrm{E}-05$ & 8.7E-06 & $7.2 \mathrm{E}-07$ & $1.8 \mathrm{E}-07$ & $-1.0 \mathrm{E}-05$ & $-1.1 \mathrm{E}-05$ & $-1.9 \mathrm{E}-05$ & $-2.9 \mathrm{E}-06$ & $1.5 \mathrm{E}-05^{* *}$ \\
\hline Research_09 & 0.121 & 0.118 & $0.076^{* *}$ & 0.003 & 0.024 & -0.021 & 0.125 & 0.012 & -0.040 \\
\hline Research_10 & 1.537 & 0.525 & -0.037 & -0.007 & 0.288 & -0.555 & $-1.840^{* *}$ & -0.314 & $0.919^{*}$ \\
\hline Research_11 & $-1.956^{*}$ & -0.789 & 0.018 & 0.008 & -0.286 & $2.389^{*}$ & 1.097 & 0.164 & $-0.750^{*}$ \\
\hline Research_12 & 1.259 & 0.245 & -0.001 & 0.003 & 0.105 & $-2.200^{*}$ & 0.697 & 0.228 & -0.246 \\
\hline Research_13 & 0.182 & -0.100 & -0.125 & 0.003 & 0.135 & 0.483 & $-1.293^{*}$ & -0.203 & $0.734^{*}$ \\
\hline Research_14 & -0.803 & 0.034 & 0.068 & -0.003 & -0.190 & 0.339 & 1.018 & 0.098 & -0.575 \\
\hline Research_15 & -0.162 & -0.074 & 0.041 & -0.003 & -0.117 & -0.493 & 0.228 & 0.027 & 0.037 \\
\hline Incentiv_00 & 0.008 & 0.180 & 0.008 & 0.002 & -0.202 & 0.352 & $1.657^{* * *}$ & 0.200 & $-0.870^{* * \star}$ \\
\hline Incentiv_01 & 0.226 & -0.051 & 0.026 & -0.001 & 0.019 & -0.098 & -0.123 & -0.048 & 0.066 \\
\hline Incentiv_02 & 0.054 & 0.120 & 0.021 & 0.002 & 0.079 & 0.400 & $0.409^{* * *}$ & 0.015 & $-0.176^{* *}$ \\
\hline Incentiv_03 & -0.205 & -0.021 & -0.011 & -0.003 & 0.018 & $1.016^{* * *}$ & 0.298 & 0.042 & -0.144 \\
\hline Incentiv_04 & 0.008 & -0.055 & -0.043 & -0.001 & -0.011 & -0.085 & $-0.500^{* * *}$ & -0.045 & 0.146 \\
\hline Incentiv_05 & 0.127 & 0.215 & -0.002 & -0.004 & 0.010 & -0.152 & $0.599^{* *}$ & 0.114 & -0.173 \\
\hline Incentiv_06 & 0.063 & 0.110 & -0.011 & 0.001 & 0.035 & 0.027 & 0.047 & 0.017 & -0.045 \\
\hline Incentiv_07 & -0.249 & 0.021 & $0.056^{* * *}$ & 0.001 & $0.250^{* *}$ & -0.054 & 0.346 & 0.069 & -0.110 \\
\hline Incentiv_08 & $-0.350^{*}$ & -0.049 & -0.021 & -0.001 & -0.039 & -0.063 & $0.395^{* * *}$ & $0.112^{* *}$ & $-0.165^{* *}$ \\
\hline Incentiv_09 & 0.020 & -0.457 & 0.071 & -0.006 & 0.031 & -0.129 & 0.067 & -0.186 & -0.234 \\
\hline Incentiv_10 & 1.340 & -0.060 & 0.214 & -0.008 & 0.072 & -0.010 & -1.628 & -0.386 & 0.623 \\
\hline Incentiv_11 & -0.135 & -0.072 & -0.045 & $1.5 \mathrm{E}-04$ & -0.186 & -0.224 & $-0.737^{\star}$ & -0.122 & 0.218 \\
\hline Incentiv_12 & -0.282 & -0.096 & -0.010 & -0.001 & 0.006 & 0.158 & 0.001 & $0.082^{* *}$ & -0.023 \\
\hline Incentiv_13 & -0.108 & -0.139 & -0.037 & 0.005 & 0.021 & -0.097 & $-0.450^{* *}$ & -0.066 & 0.131 \\
\hline
\end{tabular}




\section{Tab. 3: Results of OLS regression models (Part 2)}

\begin{tabular}{l|c|c|c|c|c|c|c|c|c}
\multicolumn{1}{c|}{ Regressor } & dPo15 & dA15 & dFS15 & dFM15 & dF15 & Im15 & dBP15 & BPR15 & VR15 \\
\hline Incentiv_14 & -0.169 & 0.011 & 0.010 & -0.001 & -0.063 & -0.025 & 0.159 & 0.034 & -0.076 \\
\hline Incentiv_15 & -0.607 & -0.372 & $0.153^{* * *}$ & 0.004 & -0.015 & 1.076 & 0.113 & -0.085 & -0.160 \\
\hline Incentiv_16 & 1.840 & $0.916^{* *}$ & 0.092 & 0.014 & -0.367 & -1.343 & $1.762^{*}$ & -0.114 & -0.291 \\
\hline Popul_15 & -0.019 & -0.031 & -0.001 & $3.4 \mathrm{E}-04$ & -0.016 & 0.135 & $-0.200^{* * *}$ & -0.022 & $0.062^{*}$ \\
\hline Unemp_15 & $-0.115^{*}$ & $-0.090^{*}$ & 0.006 & 0.001 & -0.012 & 0.009 & $-0.100^{* * *}$ & -0.033 & $0.044^{*}$ \\
\hline JobsFree_15 & 0.206 & 0.058 & 0.018 & $3.6 \mathrm{E}-04$ & 0.048 & -0.045 & $-0.211^{*}$ & $-0.070^{*}$ & 0.100 \\
\hline Active_15 & 0.024 & 0.034 & 0.000 & -0.001 & 0.018 & -0.199 & 0.266 & 0.039 & -0.098 \\
\hline Urban_14 & $-13.700^{*}$ & $-13.000^{* *}$ & 0.443 & 0.019 & 3.073 & 1.161 & 8.115 & 1.244 & $-6.230^{* *}$ \\
\hline FirmsSma_15 & 0.088 & -0.191 & $0.044^{* *}$ & -0.002 & 0.113 & 0.142 & -0.064 & -0.065 & 0.047 \\
\hline FirmsMed_15 & 3.232 & $5.584^{*}$ & -0.018 & 0.049 & -0.083 & -7.631 & 3.201 & 0.201 & -0.457 \\
\hline FirmsLarg_15 & -1.689 & 5.935 & $-5.100^{* * *}$ & 0.028 & 11.422 & 5.675 & $-56.900^{* * *}$ & -6.437 & $18.728^{*}$ \\
\hline Foreigner_15 & $-0.096^{*}$ & -0.046 & -0.005 & $2.2 \mathrm{E}-04$ & -0.022 & $0.177^{* * *}$ & -0.013 & -0.010 & 0.015 \\
\hline Immigrant_15 & $0.934^{* * *}$ & $0.593^{* * *}$ & -0.013 & 0.001 & $0.123^{*}$ & & -0.067 & 0.037 & 0.094 \\
\hline BuildPerm_15 & 0.197 & 0.059 & $-0.060^{*}$ & -0.003 & 0.043 & -0.508 & & & $0.400^{* * *}$ \\
\hline Build.Tot_15 & 0.226 & 0.071 & -0.017 & -0.001 & -0.026 & -0.281 & -0.109 & -0.007 & \\
\hline BuildPermRes_15 & 0.753 & -0.011 & 0.077 & $0.030^{*}$ & -0.055 & 1.751 & & & 0.256 \\
\hline ValResid_15 & $-1.460^{* *}$ & -0.393 & $0.116^{*}$ & -0.006 & -0.068 & $1.562^{*}$ & $1.656^{* * *}$ & $0.329^{* * *}$ & \\
\hline R-squared & 0.981 & 0.984 & 0.887 & 0.882 & 0.948 & 0.988 & 0.964 & 0.977 & 0.994 \\
\hline
\end{tabular}

Source: own

Note: T-test significance levels: * $=10 \%$ (p-value lower than 0.1 and higher or equal to 0.05$),{ }^{* *}=5 \%$ ( $p$-value lower than 0.05 and higher or equal to 0.01$),{ }^{* * *}=1 \%(p$-value lower than 0.01$)$

Significant FDIs start to appear from the year 2002. There are no significant FDIs before 2002. This shows that FDI only influences our dependent variables for 13 years. Also, there is only one case when an independent variable has an FDI p-value lower than 0.05 during the years 2014 and 2015. This shows that it takes at least two years for FDI to take effect.

There are only three dependent variables that have more than two significant FDIs (two stars, p-value less than 0.05). It is highly probable that FDls only have influence on these three dependent variables and the rest is statistical interference. The three dependent variables influenced by FDI are: small firms differential during the years 2014 and 2015 (dFS15), number of building permits in year 2015 (BP15) and the value of residential buildings during the year 2015 (VR15).

We can determine the exact effect of FDI by studying the magnitude of the coefficients of significant variables. In order to determine the total effect of FDI on difference in small firms, we have to add up all significant FDI coefficients (two or three stars with p-value less than 0.05) in the column dFS15 (small firms differential during the years 2014 and 2015) in Tab. 3. The reason for this is that if one FDI was executed, it would with time gradually move up the column dFS15 (small firms differential) in Tab. 3. It follows the simple logic that we are not interested in the effect of specific FDI in only one year but in the total effect in all years after the FDI was executed. Since the sum of all the significant FDI coefficients in the column dFS15 (small firms differential) is 2.38E-05, we compute that every 1,000 CZK of FDI increases the growth rate of small firms in the region by $2.38 \mathrm{E}-05$. Multiplying this by 100,000 , we get that $100,000,000 \mathrm{CZK}$ of FDI increases the growth rate of small firms in the region by 2.38 . The conclusion is that FDI has quite a high impact on the number of newly created firms in the region. It must be noted that our regression 
models do not include other variables which could be in some way connected with the functioning of the FDI effects. If they did, the results could be more precise and more authoritative. In any way, results of models such as ours should not be taken as precise predictions but rather as observations of general trends.

Following the same procedure, we add up all significant FDI coefficients in the column dBP15 (number of building permits during the year 2015) and we get the number $-2.85 \mathrm{E}-04$. This means that for every $1,000 \mathrm{CZK}$ of FDI the number of work permits would decrease by $-2.85 \mathrm{E}-04$. Multiplying this by 10,000 , we get that every $10,000,000$ CZK of FDI will decrease the number of building permits by 2.85 . In the same way we calculate the effect of FDI on the value of residential buildings. We can say that every $100,000,000$ CZK of FDI will increase the value of residential buildings in the region by 9.13 mil. CZK.

These findings can be interpreted as examples of specific reactions of the local environment to the inflow of FDI. In the following paragraphs, we offer interpretation of the regression results focused on the effect of FDI.

Companies in the region are reacting and attracting new investors to a varying degree. Effects of the localization of multinational companies are described for example by (Massey, 1995). A company's new branch with varying intensity is integrated into the local environment, usually depending on the extent of its development. A newly localized branch of a multinational company without links to the local environment represents an extreme scenario, which was the situation appearing more in transitive economies at the beginning of the economic transformation. A conjuncture phase of the economic cycle of the Czech economy can currently be observed, with positive macroeconomic development also supported by an inflow of foreign investment in recent years, also leading to the growth of small companies. The relevance between the inflow of FDI and the growth of local domestic companies is significant. However, a limiting factor is the ability of local and regional firms to meet the requirements of localized foreign investors. There may be large technological gaps between the incoming foreign investor and domestic companies (land, Jindra, \& Marek, 2012), limiting the possibility of developing mutual cooperation.
FDI does not have a major effect on construction activity, since a significant part of FDI flows is represented by acquisitions in the business environment. Positive dependency is more linked with investment incentives, which directly leads to new construction development. The value of permitted individual construction projects in the regions with a greater inflow of FDI has been growing over the long term as a result of greater investment activity. The unemployment level in recent years has remained at very low levels and instead there has appeared to be spillover of the work force rather than an increase in the number of available jobs.

Tab. 3 shows that government incentives most likely influence the same three dependent variables as FDI. This correspondence indicates the consistency and significance of the regression models. Also, there is potential influence of government incentives on the number of immigrants (Im15). This is in line with the basic notion of how government incentives influence the labor market: with more government incentives, there are more company branches (industrial objects, factory complexes, etc.). This leads to an increase of jobs in the region. If this gap cannot be saturated by the domestic workforce, foreign workers are needed and subsequently admitted into the country. This functioning is connected with the nature of the business cycle, as documented by Jíchová (2007; 2011).

As for the small firms differential, we use the same method to calculate the effect of GII as we did to calculate the effect of FDI. Adding up the numbers 0.0559025 and 0.153041 , we get 0.2089435 . The impact of 1 million CZK of GII is an increase in the growth rate of small firms in the region by 0.2 . Multiplying this by 10 , we get that the impact of 10 million CZK of GII is an increase the growth rate of small firms by 2 . As for the number of building permits in year 2015, we use the same method and we come up with the result that 1 million CZK of GII increases the number of building permits by 2.1. As for the value of residential buildings (VR15), we use the same method as we did in previous cases and we come up with the result that 1 million CZK of GIl decreases the value of residential buildings by 1.21 .

The general opinion is that government investment incentives increase the value of residential buildings, but regression analysis 
results shows a different impact. The reason why our analysis shows a negative correlation of government investment incentives with the value of residential buildings is that government investment incentives are a proxy variable for other socio-economic factors which decrease the value of residential buildings (e.g. a lack of business opportunities and business activities in the region) and which are not included in our model. Government investment incentives correlate with these factors because they are allocated in regions where these socioeconomic factors are strong. Taking this into account we can say that FDI and government investment incentives have similar influence on the region where they are allocated.

If we assess the impact of the provided investment incentives on the regional environment, they have an apparent indirect positive impact on the growth of the number of small businesses and start-ups in districts. The localization of investments develops the local environment from a quantitative and qualitative point of view (Guesnier, 1998) because the region gets better conditions for the establishment of new companies. The positive relationship between the location of the investment incentives and monitored indicators was apparent also in the growth of the number of building permits issued. The location of the investment incentives also increases the construction activities of companies in the region.

Construction activity generally contributes to the development of regions, development of new infrastructure and buildings for production, housing as well as has a positive influence on the GDP growth in the region. On the other hand, new development will not necessarily be linked to the increase in prices of construction and in this case, there has been a decline in new construction, which can be explained by an effort to support rather quantitative development of housing and ensure economically affordable housing for new workers. Industrial development, financed by government investment incentives, also has a negative effect on the attractiveness of housing; the development of objects with a higher price of individual construction is generally not carried out in industrial areas and their immediate vicinity.

The years of significant independent variables for government incentives range from 2000 to 2015. Thus, we can suspect that they take effect almost immediately and that the effect is still significant after 15 years. We could also talk at length about the effects of control variables. We can see that many control variables are significant. Therefore, the conclusion would be that it is important to control for these variables.

As is apparent from the table, science and research expenditures have little influence on the studied characteristics of the regions. The $p$-value of independent variables standing for research expenditures rarely goes below 0.1 and only goes below 0.05 twice. It is most likely that these cases are statistical interference rather than significant statistical findings. Therefore, we will not study those in detail. It is possible that money invested in science and research has significant results only after seven years. In this case, it would be more valuable to study this in later years.

The value of the R-squared coefficient for the model concerning small firms is 0.887 . Although this value is high enough, it is relatively lower than the values of R-squared coefficients of other models. This corresponds with the fact that the number of small firms in any region is subject to high fluctuation. However, since we do not need precise predictions of this number, the relatively lower value of the R-squared coefficient is not a problem. The R-squared coefficients of models with dependent variables building permits and the value of residential buildings (other models in which the dependent variable is influenced by FDI and GII) are also high enough to ensure good quality of these models.

\section{Conclusions}

The aim of this article was to analyze whether regionally different flows of direct foreign investment, government investment incentives as well as science and research expenditures influence the development processes of regions. The local economy can react to these financial impulses in various areas with varying intensity. Therefore, our selection of observed regional aspects includes indicators related to different socio-economic areas. In the case of both foreign direct investment and government investment incentives, the results show significant influence on the number of small firms in the region, number of building permits and the value of residential buildings. Considering 
all interconnections within the national economy and regional development, the observed effects can be described as positive. As for science and research expenditures, our results show that these take more than seven years to take effect. Unfortunately, the accessible data did not allow us to study this effect during such a long time period.

In a theoretical context, our results contribute to the development of theory in the field of foreign investment and government spending aimed at giving support to the various regions. Connections found in our study created a basis for the specification of recommendations and interpretations that could be used both in theoretical research and in practical decision-making within concrete institutions. For example, the connection of FDI with the growth of the number of small firms in the region and the fact that no connection between the realization of FDI and the number of medium-sized firms in the region has been found, calls for more in-depth research in this field as these results offer valuable insight into the functioning of the economy and the effects of FDls.

As mentioned above, the results show a significant influence of FDI and GII on several indicators included in our analysis. Also, the results show no effect on the remaining variables. This is a rather unique result distinguishing between areas where the effect of these financial inflows can be experienced and areas which remain relatively untouched by the realization of the aforementioned expenses. For example, no effect of FDI and GII has been observed in the change of population inside regions and in the growth of medium-sized firms in the regions. This division may serve as guide for further political considerations and public policy regarding FDI and GII.

As far as the influence of foreign direct investment and government incentives on the number of small firms goes, this points to their flexibility and the ability to react to changes in the changing regional environment. These impacts can be evaluated positively, since companies adapt to new requirements, qualitative demands and integration to global markets. In transitive economies, this aspect is very important. Nonetheless, the impacts of localization of companies are very diversified (Sucháček et al., 2017). Reactions of larger companies to foreign direct investment and government investment incentives were not observed. In their case, changes can be expected in a longer period as they are often integrated into different production chains at the international and global levels, without strong ties to the region.

Foreign direct investments tended to involve a search for lower production costs in regions rather than technological and research potential. These conclusions also follow the research from McDonald et al. (2018), who found that positive effects of FDI increase with greater geographic proximity to core cities. With the growth of innovation performance of the regions, there also comes the strengthening of the link between foreign direct investment as well as the development of science and research activities in addition to their internationalization (Miravitlles et al., 2013).

No link between spending on science and research activities as well as the analyzed indicators has been found. It can be said that these expenditures have had little influence on the regional development processes and their impact is more selective on the activities of specific companies than on the development of regional indicators. If there are some effects on the general regional performance, then they could be observed in longer time periods.

It can be stated that development changes on the regional level are conditioned due to a variety of factors, internal and external influences, which are mutually dependent to a varying degree. For example, there is a positive dependency between a greater number of building permits and the number of foreigners in regions with higher investment attractiveness. If we assess the regional changes comprehensively, we can identify different development processes, an increase in asymmetry, which level also leads to the forming of different development trajectories. Viturka (2010) describes them as regionally different social systems, which also require regionally different public policies. In macroeconomic terms, it can be said that as in the Baltic countries (Šimelytè \& Liučvaitienè, 2012), the policy of supporting inflows of foreign direct investment and incentives has had a positive impact on the development of the regions in the Czech Republic.

In the microeconomic dimension, investment incentives and foreign direct investment have also contributed to the restructuring of 
companies and growth in quality. For example, they have significantly transformed production in the automotive and electro-technical industry. Know-how in the form of new technology and management experience along with integration in the global production chains can also be mentioned (Deloitte, 2010). Investment incentives have been spatially concentrated differently compared to the inflow of foreign investments.

Recommendations for public and regional policy can also be drawn from research. The aim of public and regional policy is to contribute to limiting the growth of asymmetry between developed and less developed regions. They have sufficiently attractive conditions, comparative and localization advantages for investors. In 2018, the government approved an amendment to the Investment Incentives Act, which provides for investment incentives for the manufacturing industry. Public policy will be more supportive of higher value-added investments, not low-cost factories, technology centers and shared service centers. This change is intended to bring greater benefits from supported foreign investment, which will increase the competitiveness of regions. Andreff (2017) proves that the promotion of science and research as well as the development of high-tech industries led to a decline in FDI outflow. For this reason, public policy was to support R\&D and hightech sectors, for example, by amending the setting of investment incentives at a national and regional level in the priorities of regional innovation strategies. Thus, it is important to establish mechanisms for increasing the efficiency of foreign direct investment (Makiela \& Ouattara, 2018) and their impact on the growth of the competitiveness and economy of the regions. Institutions, which conduct policies concerning government incentives and foreign direct investment (e.g. Czechlnvest) in the case of Czech Republic, should take into account all interconnections and influences, some of which were found in our analysis.

Further research could be focused on the analysis of interaction between investors and the regional innovation environment, especially in the development of cooperative links in R\&D to the extent that the regional environment is able to generate innovation of usable growth of newly localized companies in the region. With a greater set of data for districts, it would be possible to create a more advanced panel regression model. Also, the influence of foreign direct investment, government incentives as well as science and research expenditures on other indicators other than these that we have used in our models could be investigated. This could yield new insight into the functioning and nature of the aforementioned financial inflows. Understanding these connections would provide a basis for further political decision-making and public policy in the area of financial incentives. Transitive economies have had different development tendencies and therefore research could also be conducted in other countries in Central and Eastern Europe. Similar analysis could also be realized in the form of case-study examples of successful and less successful regions as well as their ability to absorb and integrate companies in global production networks.

The paper presents the results of the research within the GA CR project No. 18-11299S, "The development of trajectories of traditional industries in the old industrial regions".

\section{References}

Anwar, S., \& Sun, S. (2016). Foreign direct investment, domestic sales and exports of local firms: A regional perspective from China. Journal of the Asia Pacific Economy, 21(3), 325-338. https://doi.org/10.1080/13547860.20 16.1176640 .

Albulescu, C. T., \& Tamasila, M. (2014). The Impact of FDI on Entrepreneurship in the European Countries. Procedia - Social and Behavioral Sciences, 124, 219-228. https://doi. org/10.1016/j.sbspro.2014.02.480.

Alazzawi, S. (2012). Innovation, productivity and foreign direct investment-induced R\&D spillovers. The Journal of International Trade \& Economic Development, 21(5), 615-653. https://doi.org/10.1080/09638199.2010.513056.

Alvarado, R., Iñiguez, M., \& Ponce, P. (2017). Foreign direct investment and economic growth in Latin America. Economic Analysis and Policy, 56, 176-187. https://doi. org/10.1016/j.eap.2017.09.006.

Andreff, W., \&Andreff, M. (2017). Multinational companies from transition economies and their outward foreign direct investment. Russian Journal of Economics, 3(4), 445-474. https://doi. org/10.1016/j.ruje.2017.12.008. 
Ascani, A., \& lammarino, S. (2018). Multinational enterprises, service outsourcing and regional structural change. Cambridge Journal of Economics, 42(6), 1585-1611. https://doi.org/10.1093/cje/bey036.

Asheim, B. T., \& Coenen, L. (2005). Knowledge bases and regional innovation systems: Comparing Nordic clusters. Research Policy, 34(8), 1173-1190. https://doi. org/10.1016/j.respol.2005.03.013.

Autant-Bernard, C., \& LeSage, J. P. (2011). Quantifying Knowledge Spillovers Using Spatial Econometric Models. Journal of Regional Science, 51(3), 471-496. https://doi. org/10.1111/j.1467-9787.2010.00705.x.

Bajo-Rubio, O., Díaz-Mora, C., \& DíazRoldán, C. (2009). Foreign Direct Investment and Regional Growth: AnAnalysis of the Spanish Case. Regional Studies, 44(3), 373-382. https://doi.org/10.1080/00343400802508844.

Bandelj, N. (2002). Embedded Economies: Social Relations as Determinants of Foreign Direct Investment in Central and Eastern Europe. Social Forces, 81(2), 411-444. https://doi.org/10.1353/sof.2003.0001.

Blomström, M., \& Sjöholm, F. (1998). Technology Transfer and Spillovers? Does Local Participation with Multinationals Matter? European Economic Review, 43, 915-923. https://doi.org/10.1016/S0014-2921(98)00104-4.

Bučar, M., Rojec, M., \& Stare, M. (2009). Backward FDI linkages as a channel for transferring technology and building innovation capability: The case of Slovenia. The European Journal of Development Research, 21(1), 137-153. https://doi.org/10.1057/ejdr.2008.11.

Cooke, P. (2001). Regional Innovation Systems, Clusters, and the Knowledge Economy. Industrial and Corporate Change, 10(4), 945974. https://doi.org/10.1093/icc/10.4.945.

Czechlnvest. (2017). Udělené investiční pobídky. Retrieved June 12, 2018, from https://www.czechinvest.org/cz/Sluzby-proinvestory/Investicni-pobidky.

Czech Statistical Office. (2019). Věda a výzkum. Retrieved June 27, 2014, from https://www.czso.cz/csu/czso/19-veda-avyzkum-fqqfkocpmk.

Deloitte. (2010). Finální zpráva vyhodnocení dopadů investic čerpajících pobídky a zhodnocení efektivity agentury Czechinvest. Retriewed June 2, 2018, from http://www.czechinvest.org/data/files/analyzadopadu-pobidek-na-cr-2050-cz.pdf.
Driffield, N., \& Taylor, K. (2000). FDI and the labour market: A review of the evidence and policy implications. Oxford Review of Economic Policy, 16(3), 90-103. https://doi.org/10.1093/ oxrep/16.3.90.

Dunning, J. H. (2018). Theories and Paradigms of International Business Activity. Cheltenham: Edward Elgar Publishing.

Fidrmuc, J., \& Reiner, M. (2011). FDI, Trade and Growth in CESEE Countries. Focus on European Economic Integration, 1, 70-89.

García, F., Jin, B., \& Salomon, R. (2013). Does inward foreign direct investment improve the innovative performance of local firms? Research Policy, 42(1), 231-244. https://doi. org/10.1016/j.respol.2012.06.005.

Gauselmann, A., Knell, M., \& Stephan, J. (2011). What drives FDI in Central-Eastern Europe? Evidence from the IWH-FDI-Micro database. Post-Communist Economies, 23(3), 343-357. https://doi.org/10.1080/14631377.2011.595148.

Gersbach, H., \& Schmutzler, A. (2011). Foreign direct investment and R\&D-offshoring. Oxford Economic Papers, 63(1), 134-157. https://doi.org/10.1093/oep/gpq024.

Ginevičius, R., \& Šimelytè, A. (2011). Government incentives directed towards foreign direct investment: a case of Central and Eastern Europe. Journal of Business Economics and Management, 12(3), 435-450. https://doi.org/10.3846/16111699.2011.599415.

Giroud, A., Jindra, B., \& Marek, P. (2012). Heterogeneous FDI in Transition Economies A Novel Approach to Assess the Developmental Impact of Backward Linkages. World Development, 40(11), 2206-2220. https://doi. org/10.1016/j.worlddev.2012.03.018.

Guesnier, B. (1998). Innovative Milieu and regional Development. Cybergeo: European Journal of Geography, 48. https://doi. org/10.4000/cybergeo.349.

Hardy, J., Micek, G., \& Capik, P. (2011). Upgrading Local Economies in Central and Eastern Europe? The Role of Business Service Foreign Direct Investment in the Knowledge Economy. European Planning Studies, 19(9), 1581-1591. https://doi.org/10.1080/09654313. 2011.586180.

Hlaváček, P., \& Bal-Domańska, B. (2016). Impact of Foreign Direct Investment on Economic Growth in Central European Countries. Engineering Economics, 27(3). https://doi.org/10.5755/j01.ee.27.3.3914. 
Hong, J., Zhou, C., Wu, Y., Wang, R., \& Marinova, D. (2019). Technology Gap, Reverse Technology Spillover and Domestic Innovation Performance in Outward Foreign Direct Investment: Evidence from China. China \& World Economy, 27(2), 1-23. https://doi. org/10.1111/cwe.12272.

Javorcik, B. (2012). Does FDI Bring Good Jobs to Host Countries? World Bank Research Observer, World Bank Group, 30(1), 74-94. https://doi.org/10.1596/12132.

Chen, C., Melachroinos, K. A., \& Chang, K. (2010). FDI and Local Economic Development: The Case of Taiwanese Investment in Kunshan. European Planning Studies, 18(2), 213-238. https://doi.org/10.1080/09654310903491564.

Chen, K., \& Yang, S. (2013). Impact of Outward Foreign Direct Investment on Domestic R\&D Activity: Evidence from Taiwans Multinational Enterprises in Low-wage Countries. Asian Economic Journal, 27(1), 17-38. https://doi.org/10.1111/asej.12000.

Jíchová, E. (2007). Hodnocení působení zahraničních pracovníků na trhu práce České republiky. Praha: MPSV ČR. Retrieved June 27, 2018, from https://www.mpsv.cz/cs/19018.

Jíchová, E. (2011) Hodnocení působení zahraničních pracovníků na trhu práce České republiky. Praha: MPSV ČR. Retrieved June 27, 2018, from https://www.mpsv.cz/cs/19018.

Kornecki, L., \& Raghavan, V. (2011). Inward FDI Stock and Growth in Central and Eastern Europe. Review of Economics \& Finance, 1, 19-30. https://doi.org/10.1080/08853908.2011. 604297.

Kroll, H., Zenker, A., \& Schubert, T. (2009). An analysis of the development of $R \& D$ expenditure at regional level in the light of the $3 \%$ target. Brussels: European Communities. Retrieved June 9, 2018, from http://publica. fraunhofer.de/dokumente/N-205198.html.

Makiela, K., \& Ouattara, B. (2018). Foreign direct investment and economic growth: Exploring the transmission channels. Economic Modelling, 72, 296-305. https://doi. org/10.1016/j.econmod.2018.02.007.

Massey, D. B. (1995). Spatial Divisions of Labor: Social Structures and the Geography of Production. London: Psychology Press.

McDonald, C., Buckley, P. J., Voss, H., Cross, A. R., \& Chen, L. (2018). Place, space, and foreign direct investment into peripheral cities. International Business Review, 27(4), 803-813. https://doi.org/10.1016/j.ibusrev.2018.01.004.
Meriküll, J., Poltimäe, H., \& Paas, T. (2013). International Technology Diffusion. Eastern European Economics, 51(2), 21-38. https://doi. org/10.2753/EEE0012-8775510202.

Miravitlles, P., Guitart-Tarrés, L., Achcaoucaou, F., \& Núñez-Carballosa, A. (2013). The role of the environment in the location of R\&D and innovation activities in subsidiaries of foreign multinationals. Innovation, 15(2), 170-182. https://doi.org/10.5172/impp.2013.15.2.170.

Mukherjee, A., \& Sinha, U. B. (2016). Competition, foreign direct investment and welfare. Economics Letters, 139, 43-45. https://doi.org/10.1016/j.econlet.2015.12.013.

Munemo, J. (2017). Foreign direct investment and business start-up in developing countries: The role of financial market development. The Quarterly Review of Economics and Finance, 65, 97-106. https://doi.org/10.1016/j.qref.2016.08.010.

Novák, V., \& Drdová, E. (2018). Revitalizace ekonomické výkonnosti automobilového průmyslu $v$ ČR $v$ průběhu hospodářské krize se zaměřením na Ústecký kraj. In 16th International Colloquium on Regional Sciences (pp. 168-173). Brno: Masarykova univerzita $v$ Brně. https://doi.org/10.5817/CZ.MUNI. P210-6257-2013-20.

Pelinescu, E., \& Radulescu, M. (2009). The Impact of Foreign Direct Investment on the Economic Growth and Countries' Export Potential. Romanian Journal for Economic Forecasting, 12(4), 153-169.

Santos-Paulino, A. U., Squicciarini, M., \& Fan, P. (2014). Foreign Direct Investment, R\&D Mobility and the New Economic Geography: A Survey. The World Economy, 37(12), 1692-1715. https://doi.org/10.1111/twec.12208.

Srholec, M. (2004). Prímé zahraniční investice: teorie a praxe $v$ mezinárodním srovnání. Praha: Linde.

Sucháček, J., Sed'a, P., Friedrich, V., \& Koutský, J. (2017). Regional Aspects of the Development of Largest Enterprises in the Czech Republic. Technological and Economic Development of Economy, 23(4), 649-666. https://doi.org/10.3846/20294913.2017.1318314.

Šimelytè, A., \& Liučvaitienè, A. (2012). Foreign Direct Investment Policy-Friendly Business Environment in R\&D Sectors: Baltic States versus Visegrad Countries. Journal of East-West Business, 18(1), 66-93. https:// doi.org/10.1080/10669868.2012.663737.

Švejnar, J. (2002). Transition Economies: Performance and Challenges. Journal of 


\section{Economics}

Economic Perspectives, 16(1), 3-28. https://doi. org/10.1257/0895330027058.

Todo, Y., \& Miyamoto, K. (2006). Knowledge Spillovers from Foreign Direct Investment and the Role of Local R\&D Activities: Evidence from Indonesia. Economic Development and Cultural Change, 55(1), 173-200. https://doi. org/10.1086/505729.

Tuan, C., Ng, L. F., \& Zhao, B. (2009). Chinas post-economic reform growth: The role of FDI and productivity progress. Journal of Asian Economics, 20(3), 280-293. https://doi. org/10.1016/j.asieco.2009.02.010.

Tvrdoň, M., \& Skokan, K. (2011). Regional disparities and the ways of their measurement: the case of the Visegrad four countries. Technological and Economic Development of Economy, 17(3), 501-518. https://doi.org/ 10.3846/20294913.2011.603485.

Viturka, M. (2010). Regional disparities and their evaluation in the context of regional policy. Geografie, 15(2), 131-143.

Wei, Y. D., Zhou, Y., Sun, Y., \& Lin, G. C. (2012). Production and R\&D networks of foreign ventures in China: Implications for technological dynamism and regional development. Applied Geography, 32(1), 106-118. https://doi. org/10.1016/j.apgeog.2010.06.008.

Ing. Petr Hlaváček, Ph.D. Jan Evangelista Purkyně University in Ústí nad Labem

Faculty of Social and Economic Studies Department of Regional Development and Public Administration Czech Republic petr.hlavacek@ujep.cz

Ing. Julius Janáček Jan Evangelista Purkyně University in Ústí nad Labem

Faculty of Social and Economic Studies Department of Economics and Management

Czech Republic juliusjanacek@post.cz 


\title{
Abstract
}

\section{THE INFLUENCE OF FOREIGN DIRECT INVESTMENT AND PUBLIC INCENTIVES ON THE SOCIO-ECONOMIC DEVELOPMENT OF REGIONS: AN EMPIRICAL STUDY FROM THE CZECH REPUBLIC}

\author{
Petr Hlaváček, Julius Janáček
}

This article investigates the impact of foreign direct investment, government financial incentives as well as science and research expenditures on different socio-economic development processes in the Czech Republic. These financial flows are important for economic growth of regions and constitute a substantial part of financial flows within national economies. We focus on the effect of these aspects on various indicators concerning the business environment, labor market, population growth and construction activity. The analysis is conducted using OLS regression models.

Results indicate that it takes about two years for foreign direct investment to take effect and its influence is relevant for approximately 13 years. We found that foreign direct investment has a considerable influence on the number of small firms in the region, on the number of buildings permits in the region and on the value of residential estates. Our analysis further shows that government investment incentives have an impact on similar areas as foreign direct investment, which is in accordance with the general theory of the functioning of the economy. Science and research expenditures, on the other hand, seem not to have any effect in the first seven years after the expense has been realized. In this case, science and research expenditures show a longer time to respond as far as the studied indicators are concerned.

The concrete effects of foreign direct investment and government financial incentives in terms of numerical values have been calculated using the structure of our models. The magnitude and reasons for these effects are discussed. The results of these calculations indicate that foreign direct investment and government investment incentives have significant positive effect on the development processes of regions but in specific areas only.

Key Words: Investment incentives, foreign direct investment, region, Czech Republic.

JEL Classification: R12, R53.

DOI: 10.15240/tul/001/2019-3-001 